\title{
Performance and Carcass Characteristics of Free- Range Broiler Chickens Fed Diets Containing Alternative Feedstuffs ${ }^{1}$
}

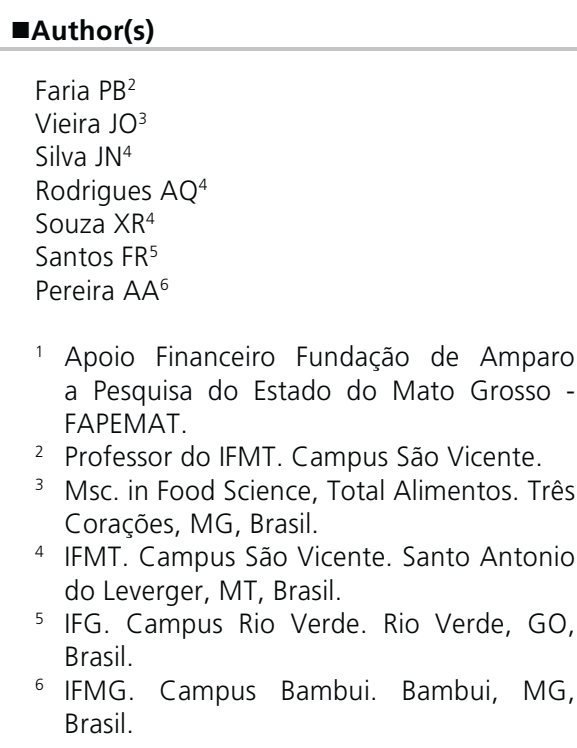

nail Address
PB Faria
Professor do IFMT
Campus São Vicente
Br 364, km 329
78.106-970. Santo Antonio do Leverger, MT,
Brasil.
E-mail: peterbfvet@yahoo.com.br

\section{-Keywords}

Alternative feedstuffs, free-range chickens, performance.

\begin{abstract}
The present study was carried out to evaluate the effects of alternative feedstuffs as partial substitutes of corn and soybean in free-range broiler diets on performance, carcass yield and technical-economic viability. A total of 400 Pescoço Pelado broilers were distributed in a completely randomized experimental design (CRD), with four treatments (treatment 1:Control; treatment 2: 10\% rice bran inclusion; treatment 3: $10 \%$ ground cassava leaves; and treatment 4: 10\% ground lead tree hay) with four replicates per treatment. Each replicate consisted of a group of 25 birds per paddock, separated per sex. Initial weight (IW), final weight (FW), body weight (BW), daily weight gain (DWG), feed intake (FI) and feed conversion ratio (FCR) were evaluated. Carcass, cuts (breast, thigh, drumstick, back, neck, leg and wings), abdominal fat and giblets (gizzard, heart and liver) yields were determined. The technicaleconomic viability of each treatment was assessed by determining the cost of feed per kg body weight, economic efficiency index and cost. The highest final weights were obtained with the use of rice bran. Rice bran and cassava leaves promoted higher carcass yield, as well as lower back and abdominal fat yields. The use of cassava leaves showed better economic efficiency among the treatments with alternative feedstuffs. The use of alternative feedstuffs at $10 \%$ inclusion in substitution of corn and soybean meal did not not result in major changes in performance and carcass parameters, and economic efficiency, and therefore, their use is recommended when the availability or the price of key ingredients, such as soybean meal and corn, increase.
\end{abstract}

\section{INTRODUCTION}

In the poultry production industry, rearing chickens in alternative or "free-range" systems is a profitable alternative both for small and medium farmers, as their products are sold to a niche market where a large number of consumers is willing to pay higher prices for them. In general, one of the main factors affecting the purchase decision mentioned by consumers of alternative chicken products is taste, which is considered different from those of conventionally produced broilers, whereas price is considered secondary (Zanussi \& Dionello, 2003).

Alternative chicken production systems are regulated in Brazil by the Ministry of Agriculture (MAPA), through its Animal Product Inspection Division (DIPOA), as stated in Circular DOI/DIPOA Number 007/99 as of May 19, 1999 (Brazil, 1999). According to the legislation, the denomination "free-range chicken" is applied to chickens fed exclusively plant ingredients of plant origin, and the use of growth promoters is not allowed. Broilers are reared in paddocks, and a density of $3 \mathrm{~m}^{2}$ of pasture per bird is recommended. Birds are slaughter at a minimum 
age of 85 days. Genetic strains should be specific for this purpose and the use of some commercial strains is not allowed.

In general, the carcass composition of free-range chickens present variations that are influenced by several factors, such as genetic strain (Coelho et al., 2007; Wood, 2005, Santos et al., 2005, Takahashi et al., 2006), sex (Grashorn \& Clostermann, 2002; Quentin et al., 2003), slaughter age (Halle \& Danika, 2001) and feeding (Berri, 2001, Rizzi et al., 2007; Sauveur, 1997).

Studies on carcass and cuts yields present useful information to guide the producer to the choice of the bird strain and management to adopt, in order to meet the expectations of the consumers, who prefer chickens with higher breast, thigh and drumstick yields (Hellmeister Filho, 2002).

In the production chain, the search for alternative feedstuffs that may adequately and economically replace the traditionally used feed ingredients allows the economic viability of alternative chicken systems. Cassava (Manihot sculenta, Cranz) is an alternative to replace traditional cereals and it is low-cost option for protein supply. Cassava leaf meal consists of primary and secondary stalks and leaves, and presents good levels of vitamins, minerals and proteins (Silva et al., 2000). Other alternative feedstuffs can be applied in broiler production: ground lead tree hay (Leucaena leucocephala), rice bran and pigeon pea (Cajanus cajan). However, as reported by Oliveira et al. (2000), these feedstuffs present anti-nutritional factors that may impair animal performance due to reductions in the use of amino acids and fat absorption.

The purpose of this study was to investigate the effects of alternative feedstuffs as partial substitutes of corn and soybean meal, in the formulations of feeds on performance, carcass characteristics and technical and economic viability of free-range broilers.

\section{MATERIALS AND METHODS}

The experiment was carried out at the experimental broiler house of the IFMT farm (São Vicente campus), located in São Vicente, MT, Brazil, between Jan 26, 2010 and Apr 18, 2010. A completely randomized experimental design with four treatments (feeds), two sexes (male and female) and four replicates per treatment was applied. In this trial, 400 "Pescoço Pelado" broilers were used. The rearing period was divided in two phases: starter (1-28 days) and finisher (29-84 days). Broilers were kept in a total area of approximately $2025 \mathrm{~m}^{2}$ divided into 16 paddocks. Each paddock was subdivided into a pasture area $\left(100 \mathrm{~m}^{2}\right)$ and a covered area $\left(3.2 \mathrm{~m}^{2}\right)$, and housed 25 birds, separated by sex and managed according to alternative rearing system practices. During the starter phase, birds were provided feed and water ad libitum and were vaccinated against Newcastle disease, Fowlpox and Gumboro. After 29 days of age, birds were allowed free access to a pasture area and feed was supplied once daily.

The treatments consisted of the replacement of corn and soybean meal by ground lead tree hay (Leucaena leucocephala), rice bran or ground cassava leaf (Manihot sculenta, Crantz). Each of these feedstuffs was included at a level of $10 \%$ in each treatment in substitution of corn and soybean meal, while the other feed ingredients remained the same. The following treatments were applied: Treatment 1 (Control diet), Treatment 2 (10\% inclusion of rice bran), Treatment $3(10 \%$ inclusion of cassava leaf meal, containing $16.42 \%$ of crude protein (CP) and $85.16 \%$ dry matter (DM)), Treatment 4 (10\% inclusion of ground lead tree meal, containing $15.60 \%$ CP and $87.08 \%$ DM). A two-phase feeding schedule was adopted, and their composition is shown in Table 1. Feed was manufactured in the IFMT Animal Science feed mill. The same diet was supplied to all broilers during the starter period, from 1 to 28 days of age, and the treatments were applied from 29 days to slaughter. Carcass yield was evaluated in 12 randomly chosen birds in each paddock, which individual body weight was similar to the average weight of the paddock.

The following performance parameters were evaluated: body weight (BW), represented by the average weight of birds in each treatment; daily weight gain (DWG), which was calculated per paddock and per feeding phase (starter and finisher); feed intake (FI), which was determined by the amount of feed offered divided by the number of birds per paddock; and feed conversion ratio $(F C)$, which was obtained by dividing feed intake by average weight gain in both periods.

Birds were slaughtered in the processing plant of IFMT, São Vicente campus (Santo Antonio do Leverger, MT), using humane methods and good hygiene practices. Carcasses were weighed after slaughter and individually packed in plastic bags. Giblets and abdominal fat were collected during evisceration. Carcasses were then chilled in a cold room for 24 hours at $5^{\circ} \mathrm{C}$. Twenty-four hours post mortem, carcasses were cut up and the commercial cuts breast, thigh, drumstick, legs, back, neck and wings were weighed. 
Table 1 - Composition of the starter and finisher diets fed to the broiler chickens during the experimental period.

\begin{tabular}{|c|c|c|c|c|c|}
\hline Ingredient & Starter & T1 & $\mathrm{T} 2$ & T3 & T4 \\
\hline Corn & 63.00 & 70.00 & 62.05 & 62.70 & 62.92 \\
\hline Soybean meal & 33.70 & 27.00 & 24.95 & 24.30 & 24.08 \\
\hline Rice bran & - & - & 10.00 & - & - \\
\hline Grond lead tree hay & - & - & - & 10.00 & - \\
\hline Ground cassava leaves & - & - & - & - & 10.00 \\
\hline Dicalcium phosphate & 2.00 & 1.80 & 1.80 & 1.80 & 1.80 \\
\hline Limestone & 0.85 & 0.75 & 0.75 & 0.75 & 0.75 \\
\hline $\mathrm{NaCl}$ & 0.20 & 0.22 & 0.22 & 0.22 & 0.22 \\
\hline $\begin{array}{l}\text { Vitamin and mineral } \\
\text { supplement }{ }^{2}\end{array}$ & 0.20 & 0.20 & 0.20 & 0.20 & 0.20 \\
\hline Probiotic $^{3}$ & 0.03 & 0.03 & 0.03 & 0.03 & 0.03 \\
\hline \multicolumn{6}{|l|}{ Calculated Value } \\
\hline $\mathrm{ME}(\mathrm{kcal} / \mathrm{kg})$ & 2,896 & 2,972 & 2,898 & 2,696 & 2,699 \\
\hline L-lysine (\%) & 1.13 & 0.97 & 0.90 & 0.83 & 0.83 \\
\hline DL-Methionine (\%) & 0.34 & 0.30 & 0.29 & 0.26 & 0.26 \\
\hline Protein (\%) & 21.00 & 18.00 & 18.00 & 18.00 & 18.00 \\
\hline \multicolumn{6}{|l|}{ Analyzed Values } \\
\hline Dry matter (\%) & 88.17 & 88.23 & 88.06 & 88.35 & 88.40 \\
\hline Ash (\%) & 5.52 & 4.59 & 5.23 & 5.15 & 5.27 \\
\hline Fat (\%) & 1.29 & 1.37 & 2.30 & 1.60 & 2.10 \\
\hline Protein (\%) & 20.71 & 18.51 & 17.16 & 16.61 & 15.36 \\
\hline
\end{tabular}

1 - T1 - Control, T2 - Treatment with inclusion of $10 \%$ rice bran , T3 Treatment with inclusion of $10 \%$ ground cassava leaves, T4 - Treatment with inclusion of $10 \%$ ground lead tree hay. 2,3 - Unimi $x^{\circledR}$

Carcass data were statistically analyzed according to a completely randomized experimental design with a $4 \times 2 \times 8$ factorial arrangement, consisting of four treatments (Treatment 1, Treatment 2, Treatment 3, Treatment 4), two sexes (males and females), and eight replicates per treatment, totaling 64 experimental units. Each experimental unit was composed of three birds, with a total of 192 birds.

In order to evaluate the economic viability of the inclusion of rice bran, lead tree hay and cassava leaves in the diets, the cost of feed per kg live weight gain (Yi) was determined, according Bellaver et al. (1985), as:

$$
Y i=(P i * Q i) / G i
$$

Where $\mathrm{Yi}$ is the cost of feed per kilogram of weight gain in the $i^{\text {th }}$ treatment; $\mathrm{Pi}$, price per kilogram of feed used in the $i^{\text {th }}$ treatment; $Q i$, amount of feed consumed in the $i^{\text {th }}$ treatment, and $\mathrm{Gi}$, weight gain of the $i^{\text {th }}$ treatment. Then, the economic efficiency index (EEI) and cost index $(\mathrm{Cl})$ were calculated as proposed by Fialho et al. (1992):

$$
\begin{aligned}
& \mathrm{EEI}=(\mathrm{MCE} / \text { CTei }) * 100 \\
& \mathrm{Cl}=(\text { CTei } / \mathrm{MCE}) * 100
\end{aligned}
$$

Where MCE is the lowest feed cost per kg observed among treatments and CTei, the cost of treatment $\mathrm{i}$.

Data were analyzed using the software program SISVAR (Ferreira, 2000). When the analysis of variance showed significant effects of treatment and sex and/ or their interaction on the analyzed parameters, means were compared by the Scott-knott test at $5 \%$ significance level.

\section{RESULTS AND DISCUSSION}

The statistical analysis did not show any interaction between treatment and sex ( $p>0.05$ ) for all parameters, as during the starter phase, broilers were fed the same diet. However, sex influenced body weight, daily weight gain and feed conversion ratio, withmales presenting better results (Table 2).

Table 2 - Body weight (BW), daily weight gain (DWG), feed intake (FI) and feed conversion ratio (FCR) of Pescoço Pelado broilers in the starter phase (1-28 days).

\begin{tabular}{lccccc}
\hline \multirow{2}{*}{ Phase } & Sex & BW(g) & DWG(g) & Fl(g) & FCR \\
\cline { 2 - 6 } Starter & Male & $151.18 \mathrm{a}$ & $16.05 \mathrm{a}$ & $35.51 \mathrm{a}$ & $2.18 \mathrm{~b}$ \\
& Female & $134.66 \mathrm{~b}$ & $13.76 \mathrm{~b}$ & $32.78 \mathrm{a}$ & $2.39 \mathrm{a}$ \\
$\mathrm{CV}(\%)$ & & 4.11 & 6.89 & 7.44 & 4.82 \\
\hline
\end{tabular}

Means followed by small letters in the same column are different by the Scott-Knott test $(p<0.05)$

This study showed better higher BW, DWG and FCR for males in the starter phase (Table 2). In the finisher phase and during the entire rearing period, males presented higher feed intake values, but no sex differences were found in FCR (Tables 3 and 4). Santos et al. (2005) reported similar findings, with higher average weight gain in males as compared to females for the strains $\mathrm{Cobb}^{\circledR}$, Paraiso Pedrês and ISA Label ${ }^{\circledR}$. These results may be attributed to the different anabolic rates between exes. Males have a higher growth rate and muscle mass, while females present higher fat deposition (Dionello \& Zanussi, 2003), resulting in higher body weight in males than in females in mature birds (Lawrie, 2005).

The different treatments during the finisher phase and the entire experimental period did not influence BW, DWG, FCR and FI values (Tables 3 and 4). The obtained DWG results are similar to those reported by Hellmeister Filho et al. (2003), who reported an average DWG of $27.05 \mathrm{~g}$ for "Pescoço Pelado"; and Santos et al. (2005), with an average DWG of $27.63 \mathrm{~g}$ for Isa Labe ${ }^{\circledR}$ in the period of 1-105 days of age. Oliveira et al. (2000), investigating diets with the inclusion of 
Table 3 - Body weight (BW), daily weight gain (DWG), feed intake (FI) and feed conversion ratio (FCR) "Pescoço Pelado" broilers in the finisher phase (29 to 84 days).

\begin{tabular}{|c|c|c|c|c|c|c|c|}
\hline \multirow{2}{*}{ Parameter } & \multicolumn{4}{|c|}{ Treatment } & \multicolumn{2}{|c|}{ Sex } & \multirow{2}{*}{ CV (\%) } \\
\hline & T1 & T2 & T3 & T4 & Male & Female & \\
\hline BW(g) & $1192.00 a$ & $1163.21 \mathrm{a}$ & $1083.92 a$ & $1096.95 a$ & $1245.93 a$ & $1022.10 b$ & 5.56 \\
\hline DWG(g) & $33.43 a$ & $31.48 a$ & $30.48 a$ & $30.44 a$ & $35.58 a$ & $27.30 \mathrm{~b}$ & 5.03 \\
\hline $\mathrm{Fl}(\mathrm{g})$ & $96.30 a$ & $94.73 a$ & $98.50 a$ & $102.56 a$ & $107.21 \mathrm{a}$ & $88.83 b$ & 4.90 \\
\hline FC & $3.10 a$ & $3.46 a$ & $3.41 \mathrm{a}$ & $3.47 a$ & $3.28 \mathrm{a}$ & $3.45 a$ & 8.93 \\
\hline
\end{tabular}

Table 4 - Initial body weight (IW), final body weight (FW), daily weight gain (DWG), feed intake (FI) and feed conversion ratio (FCR) of "Pescoço Pelado" broilers during the period of 1 to 84 days.

\begin{tabular}{|c|c|c|c|c|c|c|c|}
\hline \multirow{2}{*}{ Parameter } & \multicolumn{4}{|c|}{ Treatment } & \multicolumn{2}{|c|}{ Sex } & \multirow{2}{*}{ CV (\%) } \\
\hline & T1 & $\mathrm{T} 2$ & T3 & T4 & Male & Female & \\
\hline $\operatorname{IW}(\mathrm{g})$ & $38.52 a$ & $38.41 a$ & $38.97 a$ & $39.37 a$ & $38.78 a$ & $38.86 a$ & 2.33 \\
\hline $\mathrm{FW}(\mathrm{g})$ & $2375.72 a$ & 2309.01a & $2176.89 b$ & $2198.16 b$ & $2549.39 a$ & $1980.50 b$ & 4.15 \\
\hline DWG(g) & $27.43 a$ & $26.04 a$ & $25.10 a$ & $25.14 a$ & $29.07 a$ & $22.78 b$ & 4.99 \\
\hline $\mathrm{Fl}(\mathrm{g})$ & $75.60 a$ & 74.48a & $77.24 a$ & $79.62 a$ & $83.31 a$ & $70.15 b$ & 4.70 \\
\hline FCR & $2.81 a$ & $3.06 a$ & $3.06 a$ & $3.08 a$ & $2.91 \mathrm{a}$ & $3.10 a$ & 6.14 \\
\hline
\end{tabular}

Means followed by small letters in the same row are different by the Scott-Knott test $(p<0.05)$; T1 - Control treatment, T2 - Treatment with 10\% rice bran inclusion, T3 - Treatment with 10\% ground cassava leaves inclusion, T4 - Treatment with $10 \%$ ground lead tree hay inclusion.

lead tree and pigeon pea in broiler feeds, did not find any influence on feed intake and feed conversion ratio values in broilers in the grower period (21-42 days).

Literature reports FCR average values of 2.46 to 3.62 for "Pescoço Pelado" broilers, which are similar to the results of the present study. Variations in FCR may be due to different slaughter ages, feeding and rearing systems (Barbosa Filho et al., 2005; Hellmeister Filho et al., 2003; Santos et al., 2005; Savino et al., 2007, Takahashi et al., 2006).

Lower slaughter weights were obtained in broilers fed ground cassava leaves and lead tree hay, as well as in females (Table 4). Studying the effect of sex, Faria et al. (2010) obtained similar results at 85 days, with higher averages for males. Santos et al. (2005) evaluated the performance of Paraíso Pedrês, Isa Labe ${ }^{\circledR}$ and Cobb $^{\circledR}$ broilers during the periods 1-21, 1-49, 1-77 and 1-105 days, and found that males presented higher weight gain than females during all periods.

The highest values for final weight were found in the control and the rice bran treatment (Table 4). These values are similar to those reported by Savino et al. (2007) for "Pescoço Pelado" chickens reared until 84 days. This result supports the use of rice bran as an alternative energy source for broiler feeds, as it is rich in lipids, protein and phosphorus (Schouten et al., 2003). Despite the presence of anti-nutritional factors, rice bran does not impair broiler performance, and those these authors recommend a maximum of $12 \%$ of rice bran dietary inclusion when the feed is not supplemented with enzymes.

The treatments including cassava and lead tree hay did not allow broilers to reach the same slaughter weights as those in the other treatments (Table 4). This is probably due to the lower lipid and protein contents in those feeds, which were not sufficient to supply the birds' nutritional requirements, as reported by Campello et al. (2009).

Therefore, despite the differences in the nutritional composition of diets, this variation was not enough to cause changes in feed intake and feed conversion values. The higher body weight of the birds fed the control and rice bran diets may be related to higher nutrient density of these diets. Lewis et al. (1997) reported similar effects when evaluating two diets (conventional and alternative) in the Label Rouge ${ }^{\circledR}$ poultry production system.

In general, treatments had little influence on performance parameters, despite the possible presence of anti-nutritional factors in the feeds. Silva et al. (2000) reported similar results when replacing corn and soybean meal by cassava leaf meal in the diet of broiler chickens. According to Oliveira et al. (2000), this may be related to increased tolerance or adaptation to the anti-nutritional factors present in these feeds and / or the amount supplied was not sufficient to cause detrimental effects on performance.

The feeds containing rice bran and cassava leaves promoted higher carcass yields, as well as lower back and abdominal fat yields (Table 5). Despite the presence of anti-nutritional factors in rice bran, such as high levels of phytic acid and non-starch polysaccharides (NSP), these compounds did not cause any negative effects on performance, as shown by the high carcass yield value, which confirms the nutritional quality that feedstuff for broilers reared in alternative production systems.

The diets containing rice bran and lead tree hay resulted in lower breast yield values, and the treatments with higher giblet yields were, in descending order: ground lead tree hay, ground cassava leaves and rice 
bran (Table 5). There was no influence of treatments on thigh, drumstick, wing, neck and feet yields.

Sex influenced cuts yield, with females presenting higher breast yield as compared to males, which, in turn, presented higher thigh and leg yields (Table 5). Literature reports that, relative to carcass and cuts yield of broiler strains used in alternative production systems, females had higher breast yield, while males presented better thigh yield (Takahashi et al., 2006; Hellmeister Filho, 2002; Coelho et al., 2007; Grashorn \& Clostermann, 2002; Santos et al., 2005). According to Madeira et al. (2006), high thigh yield observed in males may be related to their higher physical activity, causing higher muscular development of the thighs.

Sex did not influence the other evaluated carcass components (carcass, drumstick, back, neck, wings and giblets yields), consistent with the reports of other authors (Campello et al., 2009). No differences in carcass yield, as influenced by sex, were found by Grashorn \& Clostermann (2002), Santos et al. (2005) and Dourado et al. (2009).

Females had higher levels of abdominal fat (Table $5)$, in agreement with the results of Grashorn \& Clostermann (2002), Hellmeister Son (2002) and Santos et al. (2005). This finding is attributed to the difference in the growth rates between males and females, and as females reach maturity earlier, larger amounts of fat are deposited in the carcass (Lawrie, 2005).

Table 5 - Carcass and cuts yield of 84-day-old Pescoço Pelado broilers.

\begin{tabular}{|c|c|c|c|c|c|c|c|}
\hline \multirow{2}{*}{ Yields (\%) } & \multicolumn{4}{|c|}{ Treatment } & \multicolumn{2}{|c|}{ Sex } & \multirow{2}{*}{ CV $(\%$} \\
\hline & $\mathrm{T} 1$ & $\mathrm{~T} 2$ & T3 & T4 & Males & Female & \\
\hline Carcass & $69.10 b$ & $71.82 a$ & $71.14 a$ & $69.53 b$ & $70.12 a$ & $70.68 a$ & 3.05 \\
\hline Breast & $26.82 \mathrm{a}$ & $25.86 \mathrm{~b}$ & $26.45 a$ & $25.69 b$ & $25.04 b$ & $27.38 a$ & 5.07 \\
\hline Drumstick & $14.68 \mathrm{a}$ & $14.51 a$ & $14.62 a$ & $15.03 a$ & $15.26 a$ & $14.16 b$ & 4.60 \\
\hline Thigh & $15.09 a$ & $15.14 a$ & $14.88 a$ & $14.66 a$ & $15.45 a$ & $14.44 a$ & 5.74 \\
\hline Back & $22.31 a$ & $20.80 \mathrm{~b}$ & $20.59 b$ & $21.61 a$ & $21.47 a$ & $21.18 a$ & 5.34 \\
\hline Neck & $7.84 a$ & $7.63 a$ & $7.58 a$ & $7.95 a$ & $7.79 a$ & $7.72 a$ & 7.67 \\
\hline Wings & $12.16 \mathrm{a}$ & $12.14 a$ & $12.19 a$ & $12.32 \mathrm{a}$ & $12.33 a$ & $12.07 a$ & 4.55 \\
\hline Feet & $4.92 \mathrm{a}$ & $5.08 a$ & $5.38 a$ & $5.39 a$ & $5.62 a$ & $4.76 b$ & 12.47 \\
\hline Abdominal fat & $2.34 a$ & $1.95 b$ & $1.73 b$ & $2.23 a$ & $1.84 b$ & $2.29 a$ & 20.62 \\
\hline Giblets & $5.58 c$ & $5.57 c$ & $6.18 b$ & $6.90 a$ & $6.01 a$ & $6.11 a$ & 7.43 \\
\hline
\end{tabular}

Means followed by small letters in the same row are different by the Scott-Knott test $(p<0.05) ; 11$ - Control treatment, T2 - Treatment with 10\% rice bran inclusion, T3 - Treatment with 10\% ground cassava leaves inclusion, T4 - Treatment with $10 \%$ ground lead tree hay inclusion.

Table 6 - Diet cost per kilogram of weight gain (FCW), economic efficiency index (EEI) and cost index $(\mathrm{Cl})$ of broilers fed diets with alternative feedstuffs (1-84 days).

\begin{tabular}{lccccccc}
\hline \multirow{2}{*}{ Parameter } & \multicolumn{4}{c}{ Treatment } & & \multicolumn{2}{c}{ Sex } \\
\cline { 2 - 4 } \cline { 7 - 8 } & T1 & T2 & T3 & T4 & & Male & Female \\
\hline FCW (R\$/kg of weight gain) & 1.46 & 1.50 & 1.47 & 1.50 & & 1.54 & 1.65 \\
$\mathrm{EEl}(\%)$ & 100.00 & 97.33 & 99.32 & 97.33 & & 100.00 & 93.33 \\
$\mathrm{Cl}(\%)$ & 100.00 & 102.74 & 100.68 & 102.74 & & 100.00 & 107.14 \\
\hline
\end{tabular}

T1 - Control treatment, T2 - Treatment with $10 \%$ rice bran inclusion, T3 - Treatment with $10 \%$ ground cassava leaves inclusion, T4 - Treatment with $10 \%$ ground lead tree hay inclusion.
Technical-economic evaluation results indicated that the control treatment presented the lowest feed cost per kilogram of body weight (FCW), better economic efficiency index (EEI) and cost index (CI) as compared with other treatments. Among the treatments with alternative feedstuffs, the cassava leaf diet showed better $\mathrm{EEI}$ and $\mathrm{Cl}$ (Table 6), although live weight at slaughter was lower.

Comparing the sexes, males showed $7 \%$ higher economic efficiency than females. This reflects the better performance of males during the experimental period as compared to females in economic terms.

In general, the use of alternative feedstuffs at 10\% inclusion in substitution of corn and soybean meal did not significantly affect production costs, despite the lower economic efficiency in relation to the control treatment. Because the use of the evaluated feedstuffs did not result in major changes in performance and carcass parameters, their use is recommended when the availability or the price of key ingredients, such as soybean meal and corn, increase.

\section{CONCLUSION}

The results of the present study showed that inclusion of up to $10 \%$ of alternative feedstuffs in the diets of free-range broilers did not cause major changes on performance and carcass parameters or in economic viability. When the evaluated alternative feedstuffs were compared, the best economic and carcass results were obtained with the dietary inclusion of ground cassava leaves.

\section{REFERENCES}

Barbosa Filho JAD, Silva MAN, Silva IJO, Coelho $A A D$, Savino VJM. Behavior and performance of broiler strains reared under semi-intensive system with shaded areas. Brazilian Journal of Poultry Science 2005; 7(4):209-213.

Bellaver C, Fialho ET, Protas JFS. et al. Radícula de malte na alimentação de suínos em crescimento e terminação. Pesquisa Agropecuária Brasileira 1985; 20(8):969-974.

Berri C, Wacrenier N, Millet N, Bihan-Duval E. Effect of selection for improved body composition on muscle and meat characteristics of broilers from experimental and commercial lines. Poultry Science $2001 ; 80(7): 833-838$.

Brasil. Ministério Agricultura, Pecuária e Abastecimento. Ofício Circular DOI/DIPOA 
n.007/99, de 19 de maio de 1999. Brasília; 1999.

Campello CC, Santos MSV, Leite AGA, Rolim BN, Cardoso WM, Souza FM. Características de carcaça de frangos tipo caipira alimentados com dietas contendo farinha de raízes de mandioca. Ciência Animal Brasileira 2009; 10(4):1021-1028.

Coelho AAD, Savino VJM, Rosario MF, Silva MAN, Castilho CJC, Spoto MHF. Características de carcaça e da carne de genótipos de frangos caipiras. Brazilian Journal Food Technology 2007; 10(1):9-15.

Dourado LRB, Sakomura NK, Nascimento DCN, Dorigam JC, Marcato SM, Fernandes JBK. Crescimento e desempenho de linhagens de aves de pescoço pelado criadas em sistema semi-confinado. Ciência e Agrotecnologia 2009; 33(3):875-881

Faria PB, Bressan MC, Souza XR Crescimento e desempenho de frangos criados em sistema alternativo. Pubvet-Londrina 2010; 4(8):761.

Ferreira DF. Análises estatísticas por meio do sisvar para o Windows versão 4.0. Anais da $45^{\circ}$ Reunião anual da região brasileira da sociedade internacional de biometria; 2000; São Carlos, São Paulo. Brasil. p. 255-258.

Fialho ET, Barbosa O, Ferreira AS. Utilização da cevada suplementada com óleo de soja para suínos em crescimento e terminação. Pesquisa Agropecuária Brasileira 1992; 27(10):1467-1475.

Grashorn MA, Clostermann G. Performance and slaughter characteristics of broiler breeds for extensive production. Archive Geflügelk 2002; 66(4):173181.

Halle I, Danicke S. Influence of diet and feeding technique on growing, feed conservation ratio and carcass composition for fast- and slow-growing broiler chickens. Landbauforschung Völkenrode 2001; 4(51):175-184.

Hellmeister Filho P. Efeitos de fatores genéticos e do sistema de criação sobre o desempenho e rendimento de carcaça de frango tipo caipira [tese]. Piracicaba (SP): Universidade de São Paulo, Escola Superior de Agricultura Luiz de Queiroz; 2002.

Hellmeister Filho P, Menten JFM, Silva MAN, Coelho AAD, Savino VJM. Efeito de genótipo e do sistema de criação sobre o desempenho de frangos tipo caipira. Revista Brasileira de Zootecnia 2003; 32(6):1883-1889.

Lawrence TLJ, Fowler VR. Growth of farm animals. New York : CAB International, 1997.

Lawrie RA. Ciência da carne. Tradução de Jane Maria Rubensan. 6 ed. Porto Alegre: Artmed; 2005.

Lewis PD, Perry GC, Farmer LJ, Patterson RLS. Responses of two genotypes of chicken to the diets and stocking densities typical of UK and 'label rouge' production systems: I. Performance, Behaviour and Carcass Composition. Meat Science 1997; 45(4):501-516.

Madeira LA. Morfologia das fibras musculares esqueléticas de frangos de corte criados nos sistemas confinado e semi-confinado [dissertação]. Botucatu (SP): Universidade Estadual Paulista, Faculdade de Medicina Veterinária e Zootecnia; 2005.

Madeira LA, Sartori JR, Saldanha ESPB, Pizzolante CC, Dal Pai Silva M, Mendes AA, Takahashi SE, Solarte WVN. Morfologia das fibras musculares esqueléticas de frangos de corte de diferentes linhagens criados em sistema de confinamento e semiconfinamento. Revista Brasileira de Zootecnia 2006; 35(6):2322-2332.

Montaldo A, Montilla JJ, Escobar J. El follage de yuca como fuente potencial de proteínas. Revista Brasileira de Mandioca 1994; 13(2):123-136. de fatores antinutricionais da leucena (Leucaena leucocephala e Leucaena cunningan) e do feijão guandu (Cajanus cajan) sobre o epitélio intestinal e o desempenho de frangos de corte. Revista Brasileira de Zootecnia 2000; 29(6):1759-1769

Quentin M, Bouvarel I, Berri C, Bihan-Duval E, Baeza E, Jego Y, Picard M. Growth, carcass composition and meta quality response to dietary concentrations in fast-, medium- and slow-growing commercial broilers. Animal Research 2003; 52:65-77.

Rizzi C, Marangon A, Chiericato GM. Effect o genotype on slaughtering performance and meat physical and sensory characteristics of organic laying hens. Poultry Science 2007; 86(1):128-135.

Santos AL, Skomura NK, Freitas ER, Sá Fortes CML, Carrilho ENVM, Fernandes JBK. Estudo do crescimento, desempenho, rendimento de carcaça e qualidade de carne de três linhagens de frango de corte. Revista Brasileira de Zootecnia 2005; 34(5):1589-1598.

Sauveur B. Les critères et facteurs de la qualité dês poulets Label Rouge, INRA - Production Animal 1997; 10(3):219-226.

Savino VJM, Coelho AAD, Rosario MF, Silva MAN. Avaliação de materiais genéticos visando à produção de frango caipira em diferentes sistemas de alimentação. Revista Brasileira de Zootecnia 2007; 36(3):578-583.

Schoulten NA, Teixeira AS, Rodrigues PB, Freitas RTF, Conte AJ, Silva HO. Desempenho de frangos de corte alimentados com ração contendo farelo de arroz e enzimas. Ciência e Agrotecnologia 2003; 27(6):1380-1387.

Silva HO, Fonseca RA, Guedes Filho RS. Características produtivas e digestibilidade da farinha de folhas de mandioca em dietas de frangos de corte com e sem adição de enzimas. Revista Brasileira de Zootecnia 2000; 29(3):823-829.

Takahashi SE, Mendes AA, Saldanha ESPB, Pizzolante CC, Pelicia K, Garcia RG, Paz ICIA, Quintero RR. Efeito do sistema de criação sobre o desempenho e rendimento de carcaça de frangos de corte tipo colonial. Arquivos Brasileiros de Medicina Veterinária e Zootecnia 2006; 58(4):624632.

Zanusso JT, Dionello NJL. Produção avícola alternativa: análise dos fatores qualitativos da carne de frangos de corte tipo caipira. Revista Brasileira de Agrociência 2003; 9(3):191-194. 